\title{
Etiology and Host Range of a Closterovirus Associated with Plum Bark Necrosis-Stem Pitting Disease
}

\author{
Diana B. Marini, Former Graduate Student, Y.-P. Zhang, Former Postdoctorate Associate, A. Rowhani, Specialist, \\ and J. K. Uyemoto, Research Plant Pathologist, USDA-ARS, all in the Department of Plant Pathology, University \\ of California, Davis 95616
}

\begin{abstract}
Marini, D. B., Zhang, Y.-P., Rowhani, A., and Uyemoto, J. K. 2002. Etiology and host range of a Closterovirus associated with plum bark necrosis-stem pitting disease. Plant Dis. 86:415-417.

Diseased plum (Prunus salicina) cv. Black Beaut trees developed stem gumming, severe bark necrosis, and stem pitting symptoms on the woody cylinder of the main trunk and scaffold branches. The sucker shoots of the peach (Prunus persica) cv. Nemaguard understocks exhibited oak-leaf patterns, but lacked the wood or bark markings. Other susceptible hosts included almond (Prunus dulcis), sweet (Prunus avium) and Japanese flowering (Prunus serrulata) cherries, and several plum (Prunus salicina) and prune (Prunus domestica) varieties. A purified preparation containing high molecular size dsRNAs was obtained initially from diseased cherry (P. avium $\times$ Prunus pseudocerasus) cv. Colt tissues. Healthy preparations were devoid of similar sized dsRNAs. Reverse transcriptase-polymerase chain reaction (RT-PCR) assays with degenerate oligonucleotide Closterovirus primers, designed from the HSP70 gene, were used to amplify two DNA fragments of 0.67 and $0.56 \mathrm{kbp}$. The larger cDNA product was cloned, sequenced (AF195501), and compared with other viral sequences. Depending on the number of nucleotides used in the comparisons, identities ranged from $77 \%$ for Grapevine leafroll associated virus to 3 to $44 \%$ for Little cherry virus- 1 . Specific primers from the $0.67 \mathrm{kbp}$ cDNA sequence were designed and used in subsequent RT-PCR assays. The associated $0.67 \mathrm{kbp}$ HSP70 amplicon of Plum bark necrosis-stem pitting associated virus was detected in all graftinoculated Prunus species and varieties except prune (P. domestica var. French Improved).
\end{abstract}

Plum bark necrosis-stem pitting (PBNSP) disease was first observed in 1986 affecting plum (Prunus salicina Lindl.) cv. Black Beaut trees in two orchards in Dinuba, CA (8). All of the Black Beaut plum trees had been whip-grafted with a single cultivar Wickson plum scion per tree to serve as a pollenizer, and all Wickson grafts failed. A year later, the same trees were grafted a second time with another source of Wickson scion wood, which successfully callused and grew. Meanwhile, scaffold branches with the failed grafts began to exude copious amounts of dark-colored gum and developed necrotic bark and stem pitting symptoms. Disease incidence approached $100 \%$, and both sites were eventually replanted. We hypothesized the first collection of Wickson scions was diseased and the second healthy.

Subsequent graft-transmission tests performed at University of California at Davis (UCD) proved the infectious nature of PBNSP (8). In the present study, an associ-

Corresponding author: J. K. Uyemoto

E-mail: jkuyemoto@ucdavis.edu

Accepted for publication 12 December 2001.

Publication no. D-2002-0214-02R

This article is in the public domain and not copyrightable. It may be freely reprinted with customary crediting of the source. The American Phytopathological Society, 2002. ated virus, and the putative causal agent, was identified as a Closterovirus and designated as Plum bark necrosis stem-pitting associated virus (PBNSPaV). The host range, symptoms induced, and development of a reverse transcriptase-polymerase chain reaction (RT-PCR) assay for the associated Closterovirus are described.

\section{MATERIALS AND METHODS}

Inoculum source. The virus source was a Black Beaut plum tree maintained at UCD that was graft-inoculated with tissue from diseased Black Beaut plum trees taken in a commercial orchard (8). In the second year postinoculation, the trunks and scaffold branches of grafted trees developed gummosis, bark necrosis, and stem pitting symptoms. In addition, sucker growth arising from peach (Prunus persica (L.) Batsch) cv. Nemaguard understocks showed chlorotic oak-leaf patterns. No wood marks were observed on the main peach trunks. Plum bark and peach bud tissues (i.e., root sucker growth) were used as inocula for graft-inoculations and as positive controls in RT-PCR assays. The inoculum source tree had previously tested negative for Prunus necrotic ringspot virus and Prune $d$ warf virus by enzyme-linked immunosorbent assay and flowering cherry (Prunus serrulata Lindl.) cv. Shirofugen indexings, viruses commonly found in Prunus species.

Plum cultivars and Prunus species. Five trees each of nine $P$. salicina and $P$. domestica L. plum cultivars-Angeleno, Black Amber, Black Beaut, Casselman, French Improved, Friar, Shiro, Stanley, and Laroda-were propagated (by a commercial propagator) on Citation rootstock (peach $\times$ plum hybrid). In spring 1997, the trees were transplanted to the field at UCD and spaced $45 \mathrm{~cm}$ apart and $90 \mathrm{~cm}$ between sets of five trees per cultivar. Choice of plum cultivar was based, in part, on the relative popularity and acreage planted in California. Later that fall, two or three trees per cultivar were graft-inoculated, each with three peach budchips. Nongrafted trees served as healthy controls. In September 2000, all plum trees were removed, trunks autoclaved, and bark tissue removed to expose the woody cylinder.

In the greenhouse, dormant seedlings of cherry (Prunus tomentosa Thumb.) cv. Nanking, cherry ( $P$. avium (L.) L.) cv. Mazzard, and peach cv. GF 305 were potted during January 1998. Later in March, three diseased peach budchips or plum bark patches per tree were graft-inoculated on three to five plants per species. All potted plants were transplanted in the field at UCD in April 1998. One to three trees per species were used as healthy controls.

In the orchard, two or three mature trees each of peach cv. Fay Elberta, cherry cv. Bing, almond ( $P$. dulcis (Mill.) D.A. Webb) cv. Mission, and cherry $(P$. avium $\times P$. pseudocerasus) cv. Colt supporting scions of flowering cherry cv. Shirofugen were inoculated with 15 peach budchips each. One healthy tree per species was included as a control.

cDNA cloning and sequencing. Purified dsRNAs were prepared as described (9) from leaves removed from inoculateddiseased and noninoculated-healthy trees of Colt cherry, Shirofugen flowering cherry, and peach suckers and bark tissues of Black Beaut plum trees. These preparations were used as templates in RT-PCR where cDNAs were amplified using the Closterovirus HSP70 degenerate primers (7). The products were resolved by electrophoresis in $1.5 \%$ agarose gel and size estimates determined with a 1-kb DNA Ladder standard (Life Biotechnologies Inc., Rockville, MD). The PCR products were extracted and purified from the agarose gels using a commercial Bio-Spin DNA purification column (BIORAD Inc., Hercules, CA) and cloned with TOPO TA Cloning kit (Invitrogen Inc., Carlsbad, CA). The cloning plasmid was pCR 2.1- 


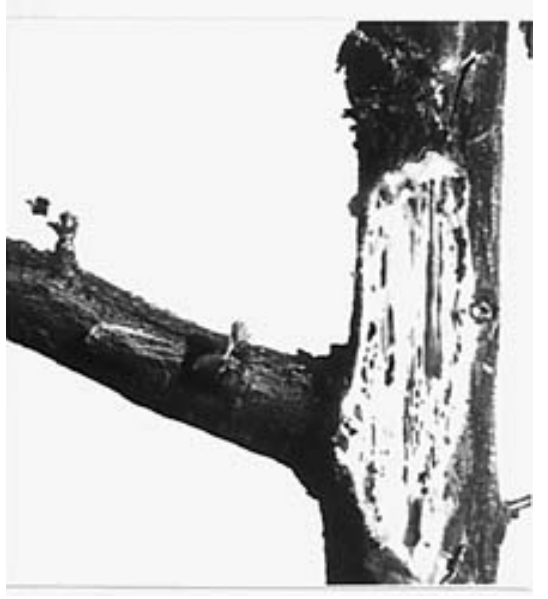

Fig. 1. Bark necrosis symptoms on Plum bark necrosis-stem pitting associated virus-infected Black Beaut plum tree.

TOPO, and the resulting recombinant DNA plasmids were purified with the QIAprep spin miniprep kit (Qiagen Inc., Valencia, CA). Recombinant plasmids were selected, and those containing inserts were identified by restriction enzyme analysis (4).

The clones with the 0.67 fragments of PCR-amplified DNAs were sequenced at the DNA Sequencing Facility, UCD. Specific primers for the associated Closterovirus were then designed from the sequence information. The RT-PCR products were separated by electrophoresis through $1.5 \%$ agarose gels using TAE buffer as per Zhang et al. (10).

Sample preparation and RT-PCR assays. A rapid assay method developed for grapevine viruses (3) was used to prepare petiole and bark tissues of diseased and healthy Black Beaut plum trees.

In May and in September 1999 (2 years postinoculation), all graft-inoculated and healthy tree species were assayed by RTPCR. Approximately $0.5 \mathrm{~g}$ of bark tissues (located immediately beneath the budchip/bark patch inocula) and leaf petioles arising nearest the inoculation sites were sampled. On some trees, leaves with viruslike symptoms along with bark samples were also assayed. All extracts were made at a tissue-to-grinding buffer ratio of 0.2 $\mathrm{g}: 5.0 \mathrm{ml}$.

\section{RESULTS}

Among field-grafted orchard trees, 85 to $100 \%$ of the inoculum peach budchips callused after a 30-day incubation period. In greenhouse inoculations, $33 \%$ of all peach budchips and 22 and $83 \%$ of plum bark patches survived on Mazzard and Nanking cherry trees, respectively. In the field, all grafted Nanking transplants died in the second growing season due to unknown causes, while all control trees survived. On GF 305 peach, $83 \%$ of the plum bark patches and all peach budchips were united with the host plant and these trees survived in the nursery.

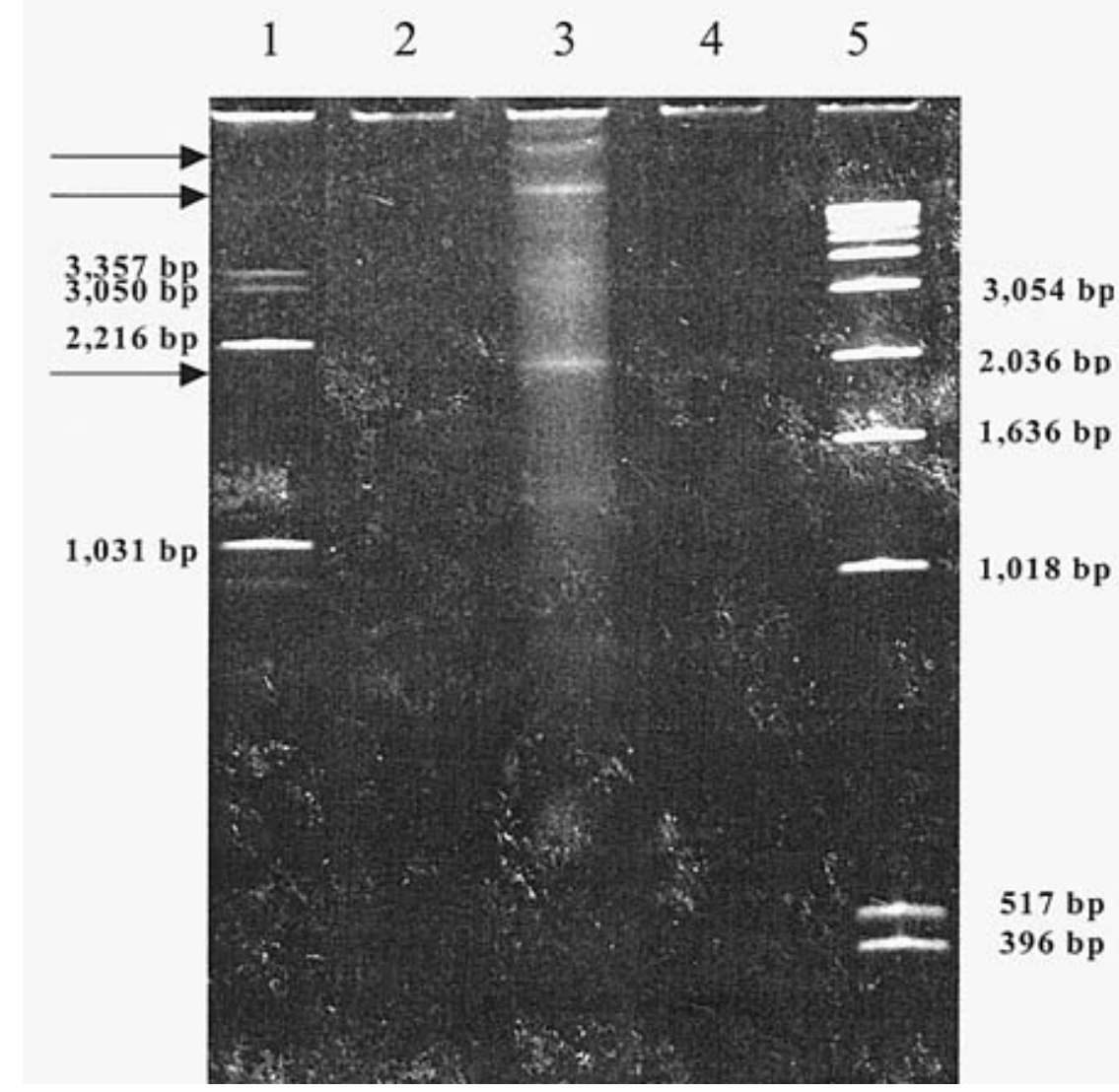

Fig. 2. Profile of dsRNAs purified from symptomatic leaves of Colt cherry trees infected with Plum bark necrosis-stem pitting associated virus (PBNSPaV). Lane 1, molecular size marker of Cucumber mosaic virus dsRNAs; lane 2, dsRNA profile of healthy Colt cherry leaves; lane 3, dsRNA profile of PBNSPaV-infected Colt leaves; lane 4, dsRNA profile of PBNSPaV-infected Colt roots; and lane 5, 1-kb DNA marker (Life Biotechnologies). Electrophoresis was done in $6 \%$ polyacrylamide gel.

After budbreak and incubation for 6 months, both inoculated Colt cherry trees developed leaves with chlorotic ring spots. On GF 305 peach, Casselman, Laroda, and Shiro plum cultivars, leaf symptoms of chlorotic ring spots, oak-leaf and linepattern were observed 12 months postinoculation. Similarly, during the second full growing season postinoculation, bark gummosis, necrosis, and stem pitting symptoms began to develop on trunks of Angeleno, Black Beaut, and Friar trees. In the third year postinoculations, bark and stem symptoms intensified (Fig. 1). Concomitantly, leaf symptoms were absent on these cultivars.

Hosts with latent infections included Fay Elberta peach, Shirofugen flowering cherry, Mission almond, Bing and Mazzard cherry, and Black Amber and Stanley plum. French Improved plum was refractory to infection by PBNSPaV. All healthy controls were normal in appearance.

Purified nucleic acid preparations from diseased leaf and bark tissues of two cherry species, plum, and peach contained three distinct dsRNA species, estimated at 17 , 16, and $2.1 \mathrm{kbp}$ in size (Fig. 2), typical of monopartite members of the Closteroviridae. Similar bands were absent in preparations of healthy tissues. Molecular size markers used in the gels were Cucumber mosaic virus (CMV) dsRNAs and the 1-kb DNA ladder standard.

Due to conserved sequences among Closteroviruses, use of the HSP70 degenerate primers resulted in amplification of two fragments $(0.67$ and $0.56 \mathrm{kbp})$. Only the larger cDNA fragment was cloned and sequenced (GenBank accession number: AF195501) and compared with sequences in the GenBank. The percentages of HSP70 nucleotide sequence identities were $44 \%$ with Little cherry virus-1 (LChV-1); 50 to $51 \%$ with Grapevine leafroll associated virus-4 and -5 (GLRaV-4, -5); 59\% with Citrus tristeza virus; and 76 to $77 \%$ with Beet yellows virus and GLRaV-3.

From our sequence data, three pairs of primers were designed and tested in all combinations. One forward primer and all three reverse primers yielded products of 414, 484, and 541 bp (Fig. 3). Sequences of the primer pair producing the largest product were: forward primer-PBNSP-3f, 5'-CTT CGG CAC TAC TTT CAG CAG $\mathrm{T}-3^{\prime}$, and reverse primer-PBNSP-2r, 5'AGT CGC ACC ACC AGT CTT CT-3'. This pair of primers was used for further testing and detection of PBNSPaV in the different test plants. Analyses with these primers revealed that with petiole tissues collected in spring and summer, the grape extraction protocol consistently yielded 


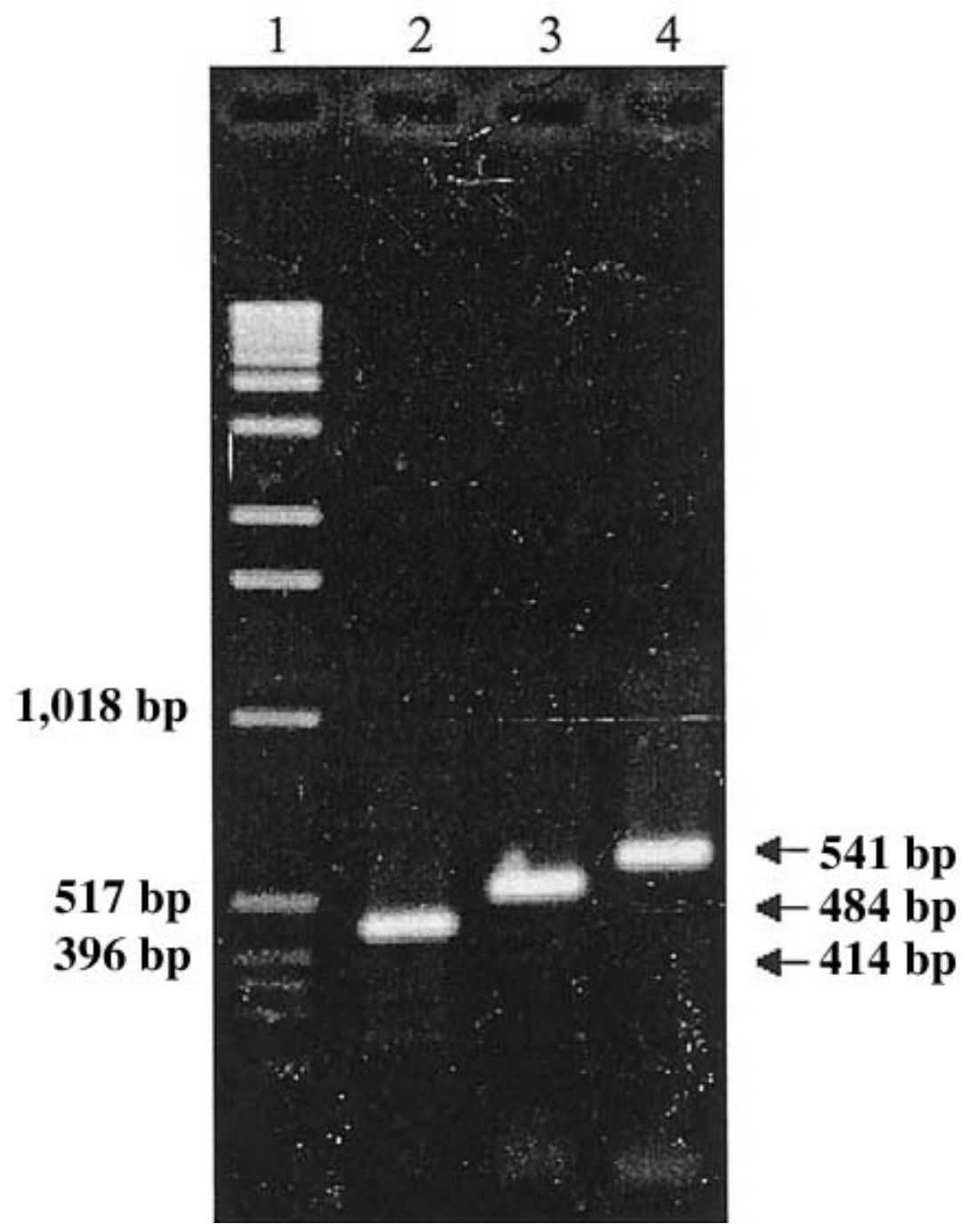

Fig. 3. An agarose gel electrophoresis profile from reverse transcriptase-polymerase chain reaction (RT-PCR) amplification of Plum bark necrosis-stem pitting associated virus (PBNSPaV) dsRNA isolated from diseased leaves of a Colt cherry tree. Lane 1 contains the 1-kb DNA ladder (Life Biotechnologies). Lanes 2 to 4 represent combinations of different primers used for PCR amplification: lane 2, PBNSPaV-3f and -1r; lane 3, $3 \mathrm{f}$ and $3 \mathrm{r}$; lane 4, $3 \mathrm{f}$ and 2r. Lane 5 is healthy control using $3 \mathrm{f}$ and $2 \mathrm{r}$ primers. Primer combination of $3 \mathrm{f}-2 \mathrm{r}$ was selected for routine virus assays.

larger amounts of the expected product compared with the small-scale extraction method (data not shown).

All Prunus hosts assayed in the study tested positive for PBNSPaV by RT-PCR assays, except French Improved plum, which tested negative in two assays, and Nanking cherry trees that died prior to performing the assay.

\section{DISCUSSION}

Several Prunus cultivars, including Colt cherry, GF 305 peach, and Casselman, Laroda, and Shiro plums, produced symptomatic leaves in the presence of PBNSPaV. In contrast, infections in Angeleno, Black Beaut, and Friar plums incited only bark and wood marking symptoms. Susceptible, latent hosts of PBNSPaV included Fay Elberta peach, Shirofugen flowering cherry, Mazzard, and Bing cher- ries, Mission almond, and the plum cultivars Black Amber and Stanley. We failed to infect French Improved plum and possibly Nanking cherry. All other grafted trees tested positive for PBNSPaV by RT-PCR assays. Noninoculated controls remained healthy and were negative by RT-PCR.

To date, only three Closteroviruses have been reported in Prunus species, and all were recovered from little cherry diseased (LChD) trees in Germany $(2,6)$. Comparisons of limited sequence data for $\mathrm{LChV}-2$ by Rott and Jelkmann (6) with another LChV characterized in North America (1) showed the viruses to be similar. Biologically, both viruses are vectored by the apple mealybug (Phenacoccus aceris (Signoret)) (5). In contrast, the vector for LChV-1 is unknown and distinct from the apple mealybug vectored viruses. Lastly, a third distinct Closterovirus was found in an
$\mathrm{LChD}$ source tree that tested negative with LChV-1 and -2 primers (6).

A tentative identification of the putative PBNSP agent was made when the banding pattern of the dsRNA species showed similarity to Closteroviruses. This was confirmed when cDNA fragments were amplified in RT-PCR assays using the HSP70degenerate primers. Definitive proof of a causal relationship, however, must await completion of Koch's postulates.

The incidence and distribution of PBNSPaV in the various Prunus orchards in California is unknown. However, virus incidence is likely low. This is because Shiro plum is used as a standard Prunus virus indicator in the California Stone Fruit and Nut Tree Registration and Certification program and would easily detect PBNSPaV. Also, development of RT-PCR assay should prove useful for rapid detection and identification of the virus.

\section{LITERATURE CITED}

1. Eastwell, K. C., and Bernardy, M. G. 2001 Partial characterization of a closterovirus associated with apple mealybug-transmitted little cherry disease in North America. Phytopathology 91:268-273.

2. Jelkmann, W., Fetchtner, B., and Agranovsky, A. 1997. Complete genome structure and phylogenetic analysis of little cherry virus, a mealybug-transmissible closterovirus. J. Gen. Virol. 78:2067-2071.

3. La Notte, P., Minafra, A., and Saldarelli, P. 1997. A spot-PCR technique for the detection of phloem-limited grapevine viruses. J. Virol. Methods 66:103-108.

4. Maniatis, T. A., Fritsch, E. F., and Sambrook, J. 1989. Molecular Cloning: A Laboratory Manual. 2nd ed. Cold Spring Harbor Laboratory, Cold Spring Harbor, NY. Book 1. P.5.31.

5. Raine, J., McMullen, R. D., and Forbes, R. D 1986. Transmission of the agent causing little cherry disease by the apple mealybug Phenacoccus aceris and the dodder Cuscuta lupuliformis. Can. J. Plant Pathol. 8:6-11.

6. Rott, M. E., and Jelkmann, W. 2001. Detection and partial characterization of a second closterovirus associated with little cherry disease, Little cherry virus-2. Phytopathology 91:261-267.

7. Tian, T., Klaassen, V. A., Soong, J., Wisler, G., Duffus, J. E., and Falk, B. W. Generation of cDNAs specific to lettuce infectious yellows closterovirus and other whiteflytransmitted viruses by RT-PCR and degenerate oligonucleotide primers corresponding to the closterovirus gene encoding the heat shock protein 70 homolog. Phytopathology 86:1167-1173.

8. Uyemoto, J. K., and Teviotdale, B. L. 1996. Graft-transmission of the causal agent of a bark necrosis-stem pitting disease of Black Beaut plum (Prunus salicina). (Abstr.) Phytopathology 86:S111-S112.

9. Valverde, R. A., Nameth, S. T., and Jordan, R. L. 1990. Analysis of double-stranded RNA for plant virus diagnosis. Plant Dis. 74:255-258.

10. Zhang, Y.-P., Uyemoto, J. K., and Kirkpatrick, B. C. 1997. A small-scale procedure for extracting nucleic acid from woody plants infected with various phytopathogens for PCR assay. J. Virol. Methods 71:45-50. 